\title{
Antimicrobial Resistant Bacteria in Health Care Facilities: Exploring Links With Water, Sanitation, and Hygiene in Gaza, Palestine
}

\author{
Reem Abushomar ${ }^{1^{*}}$, MPH; Mark Zeitoun ${ }^{2 *}$; Ghassan Abu Sittah ${ }^{3 *}$; Antoine Abu Fayad ${ }^{4 *}$; Aula Abbara ${ }^{5^{*}}$; Nassim El \\ Achi $^{6}$; Abdelraouf Elmanama ${ }^{7}$ \\ ${ }^{1}$ Joint PhD Program, Islamic University of Gaza and Al Azhar University, Gaza, Occupied Palestinian Territory \\ ${ }^{2}$ Water Security Research Centre, University of East Anglia, Norwich, United Kingdom \\ ${ }^{3}$ Conflict Medicine Program, Global Health Institute, American University of Beirut, Beirut, Lebanon \\ ${ }^{4}$ American University of Beirut, Beirut, Lebanon \\ ${ }^{5}$ Department of Infection, Imperial College, London, United Kingdom \\ ${ }^{6}$ School of Geography and the Environment, University of Oxford, Oxford, United Kingdom \\ ${ }^{7}$ Islamic University of Gaza, Gaza, Occupied Palestinian Territory \\ *these authors contributed equally
}

\section{Corresponding Author:}

Reem Abushomar, MPH

Joint PhD Program

Islamic University of Gaza and Al Azhar University

Al Remal

Gaza, 860

Occupied Palestinian Territory

Phone: 970597912917

Email: reemabushomar@gmail.com

\begin{abstract}
Background: Antimicrobial resistance (AMR) is a growing global phenomenon; however, its link to water, sanitation, and hygiene (WASH) remains underexplored, particularly in health care facilities where humanitarian crises prevail.

Objective: This study aimed to identify AMR bacteria in samples collected from WASH services in 2 hospitals in Gaza and to investigate the presence of AMR genes.

Methods: A hospital-based cross-sectional study to detect and identify antimicrobial resistance bacteria was conducted. Random samples from water, wastewater, soap, and surface swabs $(\mathrm{n}=345)$ were collected from Al-Shifa and European Gaza hospitals and screened for the presence of Enterobacteriaceae, Pseudomonas, Enterococcus, and Staphylococcusaureus. Antimicrobial susceptibility, extended spectrum beta-lactamase (ESBL) production, carbapenem resistance, and AMR genes were investigated.

Results: High levels of bacterial contamination were detected in water and surface swab samples with an overall percentage of $34.1 \%$. Moreover, $22 \%$ of the identified Enterobacteriaceae was positive for ESBL, and 14\% was positive for modified Hodge test. Over 2/3 of isolated Enterobacteriaceae in water and wastewater samples was found to be resistant to amikacin, ceftazidime, ceftriaxone, and imipenem. All Enterobacteriaceae isolates from swab samples were found to be resistant to piperacillin-tazobactam, amikacin, ceftazidime, and ceftriaxone; $13.8 \%$ of $S$. aureus in water samples was methicillin resistant. The prevalence of ESBL genes among Enterobacteriaceae isolates was 25\% OXA, 19.4\% SHV, 2.8\% KPC, 66.7\% TEM, 41.7\% blaCTXM, and 5.6\% blaCTXM-3. For carbapenem-resistant gene (MDM), the prevalence among Enterobacteriaceae was $11.1 \%$, and among Pseudomonas was $12.5 \%$. The antibiotic susceptibility profile was also presented for Pseudomonas, Enterococcus, and S. aureus.

Conclusions: The results underline the level of contamination with AMR bacteria in WASH samples and highlight the need to consider the safety of WASH service at health care facilities as an essential aspect in the fight against the spread of AMR and to interrupt nosocomial transmission.
\end{abstract}

(iproc 2022;8(1):e37246) doi: $10.2196 / 37246$

\section{KEYWORDS}

antimicrobial resistant bacteria; antimicrobial resistance genes; health care facilities; wastewater; water; sanitation; hygiene; WASH 


\section{Multimedia Appendix 1}

Potential transmission of antimicrobial resistant bacteria.

[PNG File, 138 KB-Multimedia Appendix 1]

Edited by Y Khader; this is a non-peer-reviewed article. Submitted 11.02.22; accepted 15.02.22; published 01.03.22.

Please cite as:

Abushomar R, Zeitoun M, Abu Sittah G, Abu Fayad A, Abbara A, El Achi N, Elmanama A

Antimicrobial Resistant Bacteria in Health Care Facilities: Exploring Links With Water, Sanitation, and Hygiene in Gaza, Palestine iproc 2022;8(1):e37246

URL: https://www.iproc.org/2022/1/e37246

doi: $10.2196 / 37246$

PMID:

(CReem Abushomar, Mark Zeitoun, Ghassan Abu Sittah, Antoine Abu Fayad, Aula Abbara, Nassim El Achi, Abdelraouf Elmanama. Originally published in Iproceedings (https://www.iproc.org), 01.03.2022. This is an open-access article distributed under the terms of the Creative Commons Attribution License (https://creativecommons.org/licenses/by/4.0/), which permits unrestricted use, distribution, and reproduction in any medium, provided the original work, first published in Iproceedings, is properly cited. The complete bibliographic information, a link to the original publication on https://www.iproc.org/, as well as this copyright and license information must be included. 